\title{
Hamartology and ecology: An assessment of Aruna Gnanadason's contribution to the contemporary debate
}

\author{
Dr Newton Cloete \\ Research fellow \\ Faculty of Theology \\ University of the Free State, South Africa \\ E-mail: CloeteNW@ufs.ac.za \\ Doi: https://doi.org/10.46222/pharosjot.102.030
}

\begin{abstract}
This paper is situated in the context of Christian ecotheology - offering both a Christian critique of ecological destruction and an ecological critique of Christianity. One dimension of Christian ecotheology involves ecumenical discourse on the content and ecological significance of the Christian faith. This calls for a reinterpretation of all the classic Christian symbols - in this case the doctrine of $\sin$, specifically the nature of $\sin$, explored in the light of ecological discourse. Given the radical diversity in contemporary forms of Christian ecotheology, this paper explores Indian eco-feminist Protestant theologian Aruna Gnanadason's contribution to the discourse. It starts with a brief overview of the classical understanding of the nature of $\sin$, followed by the ways in which it is re-described in contemporary ecotheological discourse. It then investigates Gnanadason's contextual approach and contribution to ecotheology through a discussion of anthropocentrism, domination in the name of differences of species, consumerist greed and alienation - profoundly influenced by her own context. The method employed encompasses ecclesial scrutiny, namely Christianity's contribution to the environmental crisis, followed by theological reflection on ecological sin, as well as alternative courses of action to appropriately address the issues in question. In conclusion, the article assesses the relevance of Gnanadason's contribution to the current ecotheological debate.
\end{abstract}

Keywords: ecotheology, anthropocentrism, domination, consumerism, alienation.

\section{Introduction}

Environmental problems such as climate change, toxic pollution, over-population and a loss of biodiversity threaten the whole of creation. The environment is a theme addressed in a wide range of disciplines, including the humanities and social sciences. In Christian theology, there has been a long-standing interest in studying the so-called "book of nature". Contemporary debates in ecological theology were prompted especially by the famous essay of the American historian Lynn White (1967) on "The historical roots of our environmental crisis". White (1967:1206) argued that Christianity "bears a huge burden of guilt" for the ecological crisis given the underlying anthropocentrism of much of (Western) theology, religiously supporting the notion that the world was created for human benefit. Many Christian theologians responded to such accusations by retrieving ecological wisdom embedded in Christianity's biblical roots, its subsequent history, Christian doctrine, liturgy, and praxis. Others acknowledged that Christian legacy is far more ambiguous than what such apologies may suggest (cf. Santmire, 1985), and have called for an "ecological reformation" of the Christian tradition. Nash (1996), for example, holds that such a reformation implies significant flaws in the Christian tradition - else a reformation would not be necessary. It also implies these flaws can be corrected - else a reformation would not be possible. 
Conradie (2006: 63) observes that this task of an ecological reformation is addressed in all the traditional sub-disciplines of Christian theology, including biblical studies, biblical hermeneutics, the history of Christianity, Christian doctrine, Christian virtues and values, liturgy and worship, preaching, ministry, pastoral care, Christian education, Christian mission, and a theology of religions. This article contribute to such discourse through a reinterpretation of the Christian doctrine of sin, more specifically, the nature of sin, from the perspective of Christian ecotheology. A common assumption, at least in Christian environmental discourse, is that the environmental crisis may be understood in terms of the structural impact of human sin. Alternatively, one may suggest that the Christian doctrine of sin offers a re-description of the roots of the crisis in terms of historical, sociological, and economic variables. This would require a basic understanding of the traditional Christian doctrine of sin - specifically the nature of $\sin$ - and the ways it has been reinterpreted in literature on ecotheology.

The Christian doctrine of $\sin$ is highly complex given the long tradition of reflection on an understanding of sin. Durand (1978:9) identifies six themes addressed in current discourse on sin, namely: the origin of sin, the relationship between sin and demon possession, the relationship between sin and suffering, the notion of original sin, the knowledge of sin, and the nature of $\sin .{ }^{1}$ In the Christian tradition, the nature of $\sin$ is defined in countless ways. In classic terms, it is described as pride (superbia), greed (concupiscentia), or moral failure (hamartia). Some argue that sin manifests in various forms (hydra), whereas others believe sin has no ontological status and can only be described as deprivation of the good (privatio boni).

Pride is the human being's desire to be like God and the rejection of God's divine superiority as Creator of all things, thereby becoming their own centre, based on self-glorification and self-love (Barth, 1961:413-415; Niebuhr, 1996:186-188, originally published 1941). Greed may be defined as continual discontent, particularly with regard to material wealth, motivated by an undue longing for acquiring and possessing in excess. It also encompasses other related sins, such as lust, selfishness and covetousness, and is often associated with sexual desire (Tillich, 1957:29; Niebuhr, 1996:228). Moral failure (hamartia) implies "missing the mark", like an archer's arrow would miss its target, and also includes other related sins, for example, apostasy, estrangement, a lack of holiness, inability to become all one can be, as well as the denial of life's intrinsic meaning and contradiction of the Word (Robinson, 1911:4243; Brunner, 1952:90-93; Tillich, 1957:45; Peters, 1994:7). Apostle Paul argues that sin is everything that is not a result of faith, or of unity with God (Peters, 1994:23-24). Sin has many faces, and can mutate from one form to another. Engel (1990:163) comments, sin is a kind of "hydra", a "monster that grows two new heads for every one that is severed". The most popular Christian notion is the "seven deadly sins" - pride, envy, and wrath (spiritual sins), and sloth, greed, gluttony, and lust (corporal sins) (Aquinas, 1991:268). Peters (1994) describes what he calls "seven steps down the path to radical evil" and illustrates its progression - from the least to the most profane: anxiety, unfaith, pride, concupiscence, self-justification, cruelty, and blasphemy. Another line of thinking holds sin is not something, but rather the deprivation of something. Sin has therefore no ontological status and can only be described in negative terms - a deprivation of the good (privatio boni) - for example nothingness, an abnormal force, total depravity, a broken relationship with God, or the "ontological impossibility" of sin (Brunner, 1952:92-93; Barth, 1958:102; 1960:349-355; Williams, 1985:198-204; Brinkman, 2003:119).

The above narratives on the nature of sin have been reinterpreted and re-defined in the light of ecological threats, described here as "ecological sin", which include "human failings ... to relate to non-human creation in ways informed by justice and peace" (Horrell, 2010:134), causing damage to ecological systems everywhere. Ecological sins may be classified into

\footnotetext{
1 For a detailed discussion see Durand (1978).
} 
various (often overlapping) categories, as discussed below.

Anthropocentrism assumes humans are the most superior entity of the universe, where everything is judged according to human perceptions, values, and experiences. Excessive value is attached to human beings, while the opposite holds true for the rest of creation. Nature is subordinated and regarded as existing for the sole objective of serving human purposes. Such assumptions typically serve to condone domination in the name of differences of species. Another way of reinterpretation follows from the notion of sin as greed and desire. The core of consumerist greed is concupiscence, together with impatience and dissatisfaction with current possessions and an insatiable desire for more. Sin leads to estrangement and broken relationships between humans and the Creator, between humans and themselves (internally), between fellow humans, as well as between humans and the rest of creation. In ecotheological terms, the latter may be expressed as alienation of humans from the earth community, alienation implying an (often passive) feeling of disaffection for the "other" - nature - as well as a deep lack of interconnectedness with other living beings. In an ecological context, sin may also be understood as sloth, suggesting moral failure, a lack of development or backwardness, as folly, referring to a lack of the required wisdom, or as denial, implying a refusal to accept the reality of the ecological crisis (Cloete, 2013:58-107; Conradie, 2017:29$60 ; 107-175)$.

Addressing the ecological crisis requires a multi-contextual and multi-stakeholder approach. It is therefore important to consider diverse contributions to the current debate, taking into account how scholars from different geographical regions, confessional backgrounds, sociopolitical contexts, genders, races, classes, etc. are influenced by such factors and respond to the crisis at hand. The objective of this article is to contribute to such literature by retrieving insights from a voice representative of the Global South - Indian feminist theologian Aruna Gnanadason. The next section therefore focuses on Gnanadason's contribution to ecotheology. She takes a feminist standpoint, and most of her views are based on her Indian context where domination in various systems is prevalent, especially among Indigenous ${ }^{2}$ and the Dalit ${ }^{3}$ people.

\section{Anthropocentrism}

Considering the earth's detrimental state, Gnanadason (2005a:44-45) argues that the Christian (especially Protestant) tradition has many flaws, for example the early missionary movements' undermining of creation's inherent value. She describes how "Greek humanism combined with biblical traditions ... gave ascendency to an anthropocentric view of the earth" due to the Bible being "read in a way that stimulates and condones anthropocentrism" (Gnanadason, 2005a:45). Even the ecumenical movement adheres to a "Euro-centric, patriarchal and anthropocentric world-view" (Gnanadason, 2005a:46). This is not surprising considering that Christianity has primarily been "human-centred and male-centred in conception and leadership" (Gnanadason, 2005a:47). At the WCC's 1966 conference, the Church and Society department declared:

We cannot ... speak of nature apart from human perception ... since man gives meaning to nature; as such he is the crown of creation. In this sense the comprehension of nature is theologically anthropocentric (Gnanadason, 2005a:49).

2 Indigenous people of India are called Adivasis, meaning "the first inhabitants or peoples of the land" (Gnanadason 2005a:2).

3 Dalits are the "out-castes" of India - a dehumanised and subjugated group of people, challenged with oppression, injustice, humiliation and violence (Gnanadason, 2005a:107). 
Gnanadason (2005a:56) holds that even liberation theologies - due to alignment with the marginalised and poor - follows an anthropocentric approach to a certain extent. She draws from Nalunnakkal (1999:90) who believes third-world methodology's core focus is challenging injustice and establishing transformation. It does not, however, entirely support the struggle against the ecological crisis, even though the earth is acknowledged as "the new poor". She also quotes Gebara (1999:46) who maintains that "the fundamentally anthropocentric and androcentric character of liberation theology appears unquestionable ... It senses no need to re-examine the cosmological and anthropological foundations of Christian faith". In response, Gnanadason (2005a:57-58) draws attention to the plight of the poor and oppressed Dalit people of India, citing a student: "Please do not ask us to be less anthropocentric, when it is only now that we Dalits are 'becoming a people' who can speak of our lives and dignity as human beings".

The WCC, largely influenced by Protestant theology, historically placed much emphasis on human- and little on earthly wellbeing. Considering the context of its establishment colonialism, poverty, struggles for political freedom, etc. - it was unavoidable. This only recently changed when Native Canadians, Indigenous people, environmentalists, and theologians joined the Vancouver assembly in 1983 and the WCC committed to fighting for justice, peace, and the integrity of creation (Gnanadason, 2005a:62-63).

Gnanadason (2005a:31-32) argues that anthropocentric attitudes should be firmly addressed, referring to ecofeminist Françoise d'Eaubonne's ecological revolution of 1974 which challenges anthropocentrism found in social justice movements, yet fails to address humanity's destructive attitude towards the earth. She quotes Russell (1985:116) who calls for an appropriate response to "humanocentrism" whereby humankind is elevated above the rest of the earth community. Previously marginalised and oppressed people found guilty of "aggressive anthropocentrism" on the basis of social justice should be ecologically challenged (Gnanadason, 2005a:58). Gnanadason (1996:77) expresses that Western feminist theologians are indeed opposing "the hierarchical chain of being and chain of command" including the concept of "humankind" over "non-human nature" and their so-called right to treat it as "private property", prevalent in the Western theological tradition.

\section{Alternatives}

Gnanadason (2005a:36-37) maintains that challenging anthropocentric attitudes calls for an "epistemological shift that renders to the earth its integrity and is open to learn from [its] wisdom". She believes much can be learned from the Orthodox tradition, which understands humankind as fulfilling the role of the "divinisation" of nature by celebrating "the divine in and with all nature", as opposed to the traditional understanding of humans as the masters of creation. Humans are thereby positioned in a divine interrelationship with God and the rest of creation (Gnanadason 2005a:60-61). In this regard, she quotes Grdzelidze (2002: 211-218):

\footnotetext{
The church blesses the waters ... and ... the fruits as a sign of recognition of the transformation of all creation through salvation and glorification. By the blessing of material things we are reminded that God's creation is sanctified ... nature is sanctified, the world is a dwelling place of divine powers (in Gnanadason, 2005a:60-61).
}

Gnanadason (2005a:60-61) contends that the human task is to thank God for creation, and also to thank God on behalf of creation as it does not have a voice of its own: Humans are "simply the tellers of its tale in a central way". Human freedom enables us to be God's coworkers or priests for a new and reconstructed creation. She cites the WCC (1988:3) phrase, "integrity of creation" - an affirmation of the earth's inherent goodness due to its establishment by "the will and love of the triune God" - and concurs that humankind do not "integrate" creation, as the latter's integrity precedes human involvement (Gnanadason, 2005a:63). 


\title{
Domination in the name of differences of species
}

Gnanadason (2005a:46) maintains that a particular understanding of Christian theology is linked to colonialism and development, significantly contributing to the modern industrial, technical and urban way of life, opposing the earth's preservation (Gnanadason, 2005a:47). ${ }^{4}$ Assessing Christianity's key role in the earth's demise, Gnanadason (2005a:48-49) emphasises that many Scriptures are ambiguous in its relation to creation, and various Christian principles support destructive attitudes towards the earth. ${ }^{5}$ While these are increasingly recognised, human beings often continue believing the earth was solely created for their kind and they can therefore do with it as deemed fit. It is precisely this attitude that constructed a flawed understanding of "development", justified theologically. A 1961 WCC statement serves as example:

The nature that scientists investigate is part of God's creation; the truth they discover is part of God's truth; the abilities they use are God-given. The Christian should welcome scientific discoveries as new steps of man's dominion over nature (Gnanadason, 2005a:49).

Gnanadason (1996:77) asserts that an anthropocentric view of the world is the very reason why Western theology never really criticised capitalism or colonialism. The WCC's Church and Society's 1966 declaration serves as example:

\begin{abstract}
The traditional Christian doctrine of creation ... teaches that nature is both to be dominated by man and to be offered to man's contemplation and awe ... Nature is under both the providence of God and the mastery of men ... They (men) can proceed with scientific and technical research and development without fear of being impious or guilty of desecration (Gnanadason, 2005a:49).
\end{abstract}

Gnanadason primarily uses examples from her Indian context in discussing domination as ecological sin. A concise overview reveals an ever-increasing list of ecological problems including deforestation, water scarcity, erection of tube wells and canals resulting in a lack of land cultivation and irrigation, floods, use of chemical fertilisers leading to water pollution and fertility loss, air pollution and waste production (Gnanadason, 2005a:7-8).

Domination by Western science and technology gained momentum after India's independence in 1948 and became more aggressive with the introduction of mega-dams, initially intended a remedy for the poverty and hunger at the time. By the start of the twenty first century, 3,600 mega-dams were erected. Exploitation of water resources reached the extent where the country fails to provide safe drinking water and basic sanitation to its population (Gnanadason, 2005a:21-22).

Damming of rivers in India significantly altered the ecology of valleys surrounding the 1300 kilometre Narmada River stretch, resulting in displacements and disruptions of millions of Indigenous people's lives, as well as destruction of forest lands covering this area. These projects cause immense poverty, especially among women, who struggle to be compensated

4 Gnanadason (2005b:162) discusses environmental degradation of India caused by British colonial rule: Around 1.7 million cubic feet of timber was annually supplied to Britain during the First World War, and 909,000 tons of timber to the British defence department alone by the end of 1944 (the Second World War), increasing deforestation in India by $65 \%$ - at the cost of Indigenous people's livelihoods. This reveals how colonial systems controlled local societies, disregarding local customary laws regulating the use of forests and preventing destruction.

\footnotetext{
${ }^{5}$ Referring to the creation story in Genesis 1, Gnanadason (2005a:48) states that the terms "subdue" and "dominion" became problematic.
} 
for the lost land, having no proof of ownership (Gnanadason, 2005a:13-14). The Indigenous and Dalit women also experience tremendous suffering due to scarcity of drinking water. Overall, ecological destruction has caused many women to commit suicide owing to their inability to provide for their families resulting from the lack of resources (Gnanadason, 2005a:22; 2005b:162-163).

Population growth also places tremendous pressure on resources, especially in developing countries. ${ }^{6}$ India's population, for example, increased from 342 million in 1947 to one billion in 2004. Fortunately, India's and other Third World countries' energy use is still at a sustainable level owing to the "hunter-gatherer and shift-cultivation communities" that help to maintain evenness with the earth's carrying ability, regardless of huge populations. Based on a 1997 study of ecological footprint, humans live too heavily on the earth, measuring 2.3 hectares of ecologically productive space amidst 1.7 hectare availability, clearly indicating that human consumption tremendously exceeds what nature produces. The US footprint measured the highest - 10.3 hectares per capita - and India at 0.8 hectares per capita. (Gnanadason, 2004:110-111). Gnanadason (2004:98) maintains that the ecological footprint left by the omnivores ("industrialists, rich famers and city dwellers, politicians, bureaucrats and technocrats") surpasses that of millions living on subsistence levels.

Gnanadason (2004:112) asserts that Europeans shows the highest population growth in history. During 1750-1930 the number of Asians increased 2.3 times and Africans (and African-Americans) less than 2 times, compared to the number of Caucasians which increased over 5 times. Moreover, the neo-Europe ${ }^{7}$ population increased more than 14 times, while the home European population increased by 269 million, astonishingly double the growth rate of the rest of the world. More than 50 million Europeans migrated to the neo-Europes between 1820 and 1930, effecting record-level emigration, along with ecological plunder. Today this adds up to "ecological debt" payable by the North to the South. Gnanadason (2004:112-113) holds that significant population decline in poor countries like Asia, Africa, and Latin America would still be extremely small compared to the decrease of only five percent in rich countries, based on current consumption levels. A small portion of the world's population enjoys the bulk of the world's resources. The so-called "omnivores", claiming unequal power, are largely responsible for consumption and pollution, thus "growth oriented development strategies that ensures a good life for a minority" is the primary driver of environmental degradation. According to Gnanadason (2005a:15-16), women and the poor suffer most at the hands of economic oppressors. The poor, however, could also be responsible for the plundering of resources in the sense of being "forced to engage in ecocide due to abject poverty and alienation from the forests they love, which have for centuries been the source of their life and livelihood."

\section{Ecofeminism}

Feminist theory is a direct response to how women experience suffering, exclusion, injustice, survival and resistance. It challenges systems of patriarchy and traditional dualisms, and emphasises the emancipation of women and the oppressed (Gnanadason, 2005a:27). Feminism led to the development of ecofeminism, which also challenges unjust economic systems and the exploitation of the earth. During the 1970s, increasing awareness of links between women and their care for creation emerged. Françoise d'Eaubonne first used the term "eco-feminisme" in her writings in 1974, calling for an ecological revolution to save the earth from destruction (Gnanadason, 2005a:31). Gnanadason (2005a:42) quotes Dietrich

\footnotetext{
${ }^{6}$ Gnanadason (2004:112) holds that a decrease in population growth may not be the answer to longterm environmental problems, yet it is a topic that should seriously be addressed.
}

7 The "neo-Europes" is the new world where Europeans settled (Gnanadason, 2004:112). 
(1996:97) who recognises that "the sexual division of labour between patriarchal technological, political and economic structures, and the privatised pursuits of mothering and nurturing, lies at the root of the ongoing ecological destruction". Thus, for feminist theologians, "liberation of the poor and the well-being of nature [are] two sides of the same coin" (Gnanadason, 2005a:78).

Gnanadason (2005a:32-34) believes women define ecofeminism based on their own contexts, and that there should be distinguished between First- and Third World ecofeminists, considering diverse challenges and worldviews. She argues that when connections between human relations and ecological destruction are analysed, the former primarily take into account gender issues, whereas the latter also include links between classism and racism (white supremacy). She therefore suggests that Third World ecofeminists employ the term "feminist environmentalism" as opposed to "ecofeminism", as it encompasses the experiences of Third World women. Gnanadason quotes the following 1988 WCC statement:

The drive to have 'mastery' over creation has resulted in the senseless exploitation of natural resources, the alienation of the land from people and the destruction of Indigenous cultures. It ignores the experience of oppressed peoples like blacks and women who suffer under its weight (Gnanadason, 2005a:63).

With regard to female connotations associated with nature, for example, "Earth Goddess" and "Mother Earth", Gnanadason (2005a:5) holds these are based on the notion that the power of women flows from the power of nature. She states that in pre-Aryan thought, women's shakti (power or energy) is derived from prakriti (nature), the latter considered the embodiment of feminine energy. It is therefore not surprising that violence against the earth is often expressed in the exact terms used to describe violence against women (Gnanadason, 2006:19). ${ }^{8}$ Gnanadason (1992:29-41) refers to this feminine power as the spirituality driving the struggle for liberation of the oppressed - both people and the earth. She quotes Itwari Devi, a leading female figure in the struggle faced by oppressed women due to mining operations in the Himalayan Mountains:

\begin{abstract}
Our power is nature's power; our shakti (power) comes from prakriti (nature). Our power against the contractor comes from these inner sources, and is strengthened by his trying to oppress and bully us with his false power of money and muscle ... They stoned our children and hit them with iron rods, but they could not destroy our shakti (quoted in Gnanadason, 1992:30).
\end{abstract}

\title{
Alternatives
}

Gnanadason (2005a:53) draws attention to an understanding of "dominion" not as domination but as servanthood, implying an attitude of loving care towards the earth. She refers to Moltmann (1985:73), who reckons that The Sabbath - instead of humans - is the crown of creation, as the creation story finds completion in it. She also quotes Ruether (1992: 21) who states that God is the possessor of creation and all it contains, and "[h]umans are given usufruct of it", fulfilling the secondary role of "royal stewards". Gnanadason (2005a:54) further makes reference to McFague and Fowler, who both challenge the term "stewardship". McFague (1997:1) states that this term is based on the notion of conserving the earth for future generations - of humans. Fowler (1995: 85) believes that stewardship only seems fit "in the metaphor of deep, complete caring" which "has nothing to do with human authority in a

\footnotetext{
8 In India, for example, population control programmes implemented for the purpose of protecting the earth from over-population are a concern for its eco-feminist movement due to its ruthless invasion into women's bodies that supports forced controls (Gnanadason, 2004:113).
} 
hierarchical universe".

Gnanadason (2005a:55) questions the degree of attention drawn to Genesis 1-2 in terms of creation and its anthropocentric element, suggesting we start looking at the Bible holistically, taking into account the diverse creation stories ${ }^{9}$, improving our understanding of our role in God's creation: "Theology needs to find alternative ways to structure our relationships with God and with the earth and the need of the hour is to find the spiritual resources to do this."

Gnanadason (2005a:77-78) believes environmental racism is an issue requiring serious consideration. The WCC is actively ensuring environmental justice by changing the quality of life and also creating a cleaner environment. This also relates to challenging and defeating all systems of domination that support the advancement of some over others based on race or ethnicity. The WCC, for example, has committed itself to triumphing over environmental racism manifested in the expropriation of ecosystem peoples' land, livelihood, and knowledge systems. ${ }^{10}$

Gnanadason (2005a:6) draws attention to India as well as other Third World countries where women play a prominent role in retaining prudent care traditions and resisting ecologically destructive developments. In fighting for the earth's preservation they also protect their own survival (Gnanadason 2005a:35). Gnanadason (2005a:38-40) has high regard for the ecological wisdom of India's Indigenous and Dalit women. Seeing their own existence intertwined with creation, they share nature's motherhood and life-giving qualities, and this special bond enables them to actively challenge destruction of the earth. She therefore believes that "a new feminist epistemology" should be based on the experiences of such women who uphold an ethic of care for the earth and resist developments endangering this relationship. It will have to search for methods of undoing damage done to the earth as a result of dominant scientific and technological thought, and call for a redefinition of the terms "good", "just", and "sustainable". For Gnanadason (2005a:91), the concept of "grace" plays a crucial role. She understands grace as "that which enables us to love the earth and to work for justice", and developed the term "brown grace", representing the Indigenous people's prudent care traditions. ${ }^{11}$ Her ultimate call is for all humans to follow this example, illuminating hope for peaceful and harmonious living between all created beings (Gnanadason, 2005a:95-96).

Gnanadason (2005a:40-41) states that in India "motherhood" is also an essential concept, manifested in humankind's unique bond with the earth, strengthened by interdependence and life-sustenance. Women apply "motherhood" as theological value in constructing a new theological vision for the earth based on a feminist ethic of care, and are not interpreted traditionally as female fertility and creativity powers should be freed from patriarchal connotations. In this way, "a new resource to inspire both a caring attitude and an

\footnotetext{
${ }^{9}$ Gnanadason (2005a:52) states that Genesis 4-11 has a communitarian focus and Genesis 4 highlights social responsibility. She holds that the Psalms, Deutero-Isaiah, and the Wisdom books, foster an ethic of care for the earth.

10 Gnanadason (2005a:78) states that overcoming sexism is part of this concern. An important WCC initiative (1988-98), entitled SISTERS (Sisters in Struggle to Eliminate Racism and Sexism), emphasised the effect of environmental racism on women (and children), believed to be mostly affected by its devastating consequences. A lack of basic common goods, for example, air, clean water, etcetera, primarily inflicts harm on their bodies and livelihoods, and therefore the "ecological debt to women" should be prioritised in discourse on finding alternatives to globalisation.
}

11 Gnanadason (2005a:91-95) states that "brown grace" is an addition to McDaniel's concepts of "green grace" and "red grace". She cites McDaniel (1997: 107) who defines green grace as "the healing and wholeness that we find when we enjoy rich relations with plants, animals and the earth'. "Red grace" is nurturing and caring "for the gifts of creation, symbolised in the blood of Christ". 
understanding of political engagement for environmental care" can be developed. She cites Dietrich (1996:97), highlighting the experiences of India's marginalised communities:

If we recognize God as mother, then motherhood and nature must also be the guiding principle for the reorganization of economic and political structures. Motherhood, the continued blessing over the good creation ... not tied to the confines of patriarchal society (Gnanadason, 2005a:41-42).

Creation is undeniably in need of humankind's mothering, and therefore an ethic of care rooted in motherhood needs further exploration and discussion to end destruction and ensuring the earth's healing (Gnanadason, 2005a:42-43).

\section{Consumerist Greed}

Gnanadason (2005a:45) affirms that the Christian tradition is not without fault considering exploitation of the earth's resources for personal gain. Throughout history various Scriptures played a major role in inciting human greed. ${ }^{12}$ Moreover, not even environmental theologians adequately respond to environmental injustice and the effects of power abuse on the earth. Gnanadason (2005a:50-51) states that the connection between Christian theology of dominion and Western science, technology and capitalism requires serious consideration, taking into account the flawed understanding of development resulting in a culture of industrialisation, detrimental to the earth's survival.

Since India attained independence in 1948, the capitalist class, supported by government, significantly contributed to the country's ecological demise. Considering scientific and technological developments at the time, the foundation for industrialisation and its profit motive was laid (Gnanadason, 2005a:21). Gnanadason (2005a:22-24) affirms that the World Bank (WB) and International Monetary Fund (IMF) are largely responsible for the imposition of several conditions perpetuating private companies' greed, the most distressing one being the privatisation of water. As public good, supposed to be state-controlled, water is turned into a private good, controlled by the corporate sector. Transnational companies regard it a treasure - the "oil of the twenty first century" - that now became a scarce resource as numerous companies obtained the right to extract it for industrial purposes, bottle and sell it, denying countless of the poor their basic human right to clean water in the process. Small farmers sell their water rights to these corporations and together with the WB and IMF, the corporate sector "has managed to turn this ... 'common' resource into a tradable, profitable and economic product to be owned, over-exploited, marketed and sold to whoever can pay for it". Even more appalling is that in certain countries the World Bank sets water privatisation as precondition for obtaining a loan, ultimately doubling the price of water. These respective governments' water department - a large public service - is consequently closed down, leaving thousands of people unemployed. The WB and IMF apply three methods for water privatisation: governments either sell public water delivery and treatment systems to private corporations; or the latter take over water service delivery and income collection through long-term leases or concessions; or governments contract corporations to manage water services in return for an admin fee. Water trading is a lucrative business for the corporate sector, continually growing at a rapid pace (Gnanadason, 2005a:24). Gnanadason (2005a:26) contends that as an essential good, water should not be treated as commodity with the aim of profit-making, but as God's gift, conserved for the use of the entire Earth.

Gnanadason (2005a:1-2) notes that ecological damage in India due to exploitation by the wealthy and powerful is a burgeoning reality. She recalls the once green, rich and luscious Thittuvillai village, surrounded by the fertile Western Ghats mountains, including Thadagathi.

\footnotetext{
${ }^{12}$ For example John 10:10, 2 Corinthians 8:9 and 2 Corinthians 9:10-11.
} 
Over time this once fertile land, nurtured by mountain streams and lakes, started fading away. Presently, "Thadagathi lies there as a mountain ... lost out to the selfish greed of the powerful one who considered hunting to be his birthright" (Gnanadason, 2005a:2). Granite and other minerals are mined to the point of exhaustion and water sources are channelled to a nearby region for industrial purposes. Indigenous inhabitants of the land - struggling farming communities - face habitat displacement and are forcefully moved to nearby districts (Gnanadason, 2005a:3). Although India is acclaimed for its rapid economic growth, one needs to consider the dreaded question: At what cost? The ecological cost is indeed high considering industrial development over the past two centuries, with overuse and exploitation of resources spiralling out of control (Gnanadason, 2005a:8-9). In Gnanadason's opinion, women are most likely affected by such developments. She puts it as follows: "They saw the way in which the 'civilizing' influence of those who came from outside threatened to destroy them. The outsiders came with their English schools, cinema houses and 'urban ways' ” (2005a:11).

Gnanadason (2004:104) defines "environmental racism" as a phenomenon occurring when environmental degradation is connected to the accumulation of profits by advantaged groups. One example is the "historical double standard" - what is tolerable in a specific community is not necessarily acceptable in another - apparent in the ways natural resources are extracted from the areas that racially oppressed populations traditionally inhabit. Attempting to ensure the country's development, the Indian government, for example, has given national and multinational companies permission to exploit these populations' lands. Other examples include the Ogoni and other Niger Delta Indigenous inhabitants of Nigeria, the Northeast Columbian U'wa people and the Amungme people of West Papua.

With regard to India, Gnanadason (2005a:12-13) draws specific attention to industrial projects in the Koraput district of Orissa resulting in the displacement of numerous Indigenous people. Multinational companies acquired significant portions of land for bauxite mining, denying these people their civil rights and leading to ecological degradation. Gnanadason (2004:104-105) discusses these projects in detail, including mining of the sacred Adivasis hill, the Gandhmardhan. India has an excess of bauxite, and the Indigenous people produced aluminium long before industrialisation, using suitable technologies, yet Bharat Aluminium Company (BALCO) started operations in 1985. BALCO primarily exports aluminium to industrialised states, such as Japan, that closed plants for environmental reasons and to avoid the high associated energy cost. This clearly illustrates how developed countries thrive on the ecological degradation of another.

Gnanadason (2004:107-108) asserts that dumping of toxic waste in racially oppressed people's habitations represents another type of environmental racism. Toxic waste is either dumped in areas occupied by the poor minority in wealthy countries, or in areas occupied by "poor developing nations". When affluent countries cannot dump waste in their own habitats, it is disposed of "either in the global commons of the oceans and the atmosphere or through their sale to Third World societies plagued by foreign debt". According to Gnanadason (2004:108), they are largely responsible for the world's hazardous waste. For years, they have been transferring waste to poor Third World countries through international waste trade. From 1989 to 1994 , OECD countries ${ }^{13}$ transferred an estimated 2,611,677 metric tons of hazardous waste to non-OECD countries. Bangladesh, India, and Pakistan received $53 \%$ of the USA's plastic waste in 1993. Britain transferred 10 thousand tons of metal waste to India in 1992, and India received 5 million tons from Germany in 1989. In 1992, India received 1,300 tons of tin waste from Australia and 7,000 tons of plastic by Pepsi Cola. The 1998 Basel Convention is an international treaty agreed on by governments to prevent OECD countries from exporting waste to Third World countries. Gnanadason (2004:108), however, claims that many countries

\footnotetext{
${ }^{13}$ Organization for Economic Cooperation and Development.
} 
have not upheld it, and thus question its effectiveness.

Gnanadason (2004:109) maintains that control of knowledge systems is also a form of environmental racism. She quotes from the 2001 WCC Conference on Ecology and Faith:

Globalization goes beyond direct attack on land to monopolization of indigenous knowledge systems, which are sustainable and eco-friendly by their very nature. Trade Related Intellectual Property Rights (TRIPS) and other international conventions, thus, legalize bio-piracy in favour of the biotechnology industry (Gnanadason, 2004:109).

This statement indicates how certain legal procedures weaken Indigenous knowledge. Biopiracy ensures that "control is kept over traditional wisdom through patent rights of plant life and other life forms". Once again, the Indigenous people and racially oppressed are the victims (Gnanadason, 2004:109).

At the 1998 WCC Assembly consensus was reached that globalisation qualifies as a modern form of domination, driven by economic powers which are "as insidious as political colonizers". Condemning this "consumerist monoculture" that promotes unequal power distribution and enables uncontrollable poverty, the assembly noted that globalisation disregards the ecological consequences of its unjust economic principles (Gnanadason, 2005a:52), among others promoting unlimited economic growth, disregarding sustainability for the sake of economic growth, as well as governments renouncing responsibility to guard public goods to the satisfaction of private corporations (Gnanadason, 2005a:70-71).

\title{
Alternatives
}

Gnanadason (2005a:37) supports an "ethic of care" linked to "a caring economy" opposed to a culture of consumerist greed, along with the WCC that is actively developing alternatives to globalisation. She quotes Peralta (2004:36) who asserts: "Feminist economists have been advocating for ... [a] care economy in all national income accounts and ... care work in all economic models and analyses".

In addition to the above, the WCC negates the term "sustainable development" due to its contradictory connotations, believed to promote unlimited economic growth and increasing production and consumption for the purpose of profit-making. It instead prefers the term "sustainable communities" as it emphasises the development of communities, including the earth as community (2005a:65-66). Together the churches made the following affirmation:

\begin{abstract}
We will resist the claim that anything in creation is merely a resource for human exploitation. We will resist species extinction for human benefit; consumerism and harmful mass production; pollution of land, air and water; all human activities which are now leading to ... the disintegration of creation (Gnanadason (2005a:70).
\end{abstract}

Furthermore, the WCC is committed to defying all forms of economic injustice embedded in globalisation. Its life-centered vision for the earth encompasses inclusive participation; equity amongst all life forms; responsibility towards the entire creation through accountability; and a commitment to sufficiency as the basis to meet all basic needs, yet improving the quality of life (Gnanadason, 2005a:76).

Gnanadason (2005a:77) contends that finding alternatives to globalisation should be prioritised in ecological discourse. She raises the issue of ecological debt whereby relevant users pay for damage caused by their overuse and exploitation of natural resources by cancelling Third World economic debt. She maintains that "racist patterns in the distribution of negative economic and environmental consequence" should also be seriously addressed. 
Gnanadason (2004:109-110) concludes that it is a misconception that only technologies of the world's developed parts hold answers to current questions on environmental degradation. She notes growing admission to the "wisdom in earth care that are rooted in the traditions of prudence of ecosystem peoples and in the technologies they craft". For centuries the wisdom and knowledge of the racially oppressed (the Adivasis and Dalits) were systematically disregarded and repressed and it is imperative that it now receives prominence in reversing ecological damage. She quotes Shiva (1989:224) who states:

\begin{abstract}
The intellectual heritage and ecological survival lies with those who are experts in survival. They have the knowledge and experience to extricate us from the ecological cul-de-sac that the western masculinist mind has maneuvered us into. And while Third World women have privileged access to survival expertise, their knowledge is inclusive. The ecological categories with which they think and act can become the categories of liberation for all, for men as well as for women, for the west as well as for the non-west, for the human as well as the non-human elements of the earth (Gnanadason, 2004:110).
\end{abstract}

\title{
Alienation of humans from the earth community
}

According to Gnanadason (1996:77), "western patriarchal theology" significantly influenced the Christian tradition. Dualistic thinking, including man/woman, nature/culture, flesh/spirit, and body/mind, became an inherent part of it. She strongly argues against hierarchies of male over female, soul over body, and spiritual over natural world, which according to her are even evident in the writings of patristic fathers such as Augustine. This worldview maintains that women were created to cooperate with the male seed and procreate, and the earth for procreating and fulfilling the biblical command in Genesis 1:28 - to be filled with and subdued by humankind.

Gnanadason (2005a:47) argues that Christianity "has been dysfunctionally and destructively dualistic in many forms, including the fateful splitting ... of humanity from the rest of creation". For Gnanadason (1996:77) this dualism is prominent as its continued influence on Christianity motivates and "legitimizes the arrogant and decisive 'lordship' of humankind over nature". She quotes Robert Solow who states: "The world can, in effect, get along without natural resources, so exhaustion is just an event, not a catastrophe". ${ }^{14}$

For Gnanadason (1994:183) the bond between women and the earth is sacred. She holds that in the Indian culture, which is inherently patriarchal and "has reduced women to subordinate roles through their traditional mothering and nurturing", exploitation of the earth subjected this intrinsic bond to abuse and brokenness, thus both women and nature are sufferers of exploitation. She believes that patriarchy represents the foundation "for associating women and nature with the base, the inferior, the degraded - to be appropriated, used, abused and discarded". Using the damming of rivers in India as illustration, she affirms: "All this is indeed violence against the people who will be displaced. It is intentional death to the land. It is an intentional way to break a people's sacred bond with the earth" (Gnanadason, 2005a:15).

Through our callous disregard of creation's gifts we wound the earth and consequently also the body of God (Gnanadason, 2005b:169-170). Humans are separated from fellow humankind and from 'otherkind' (Gnanadason, 2005a:44). Gnanadason (2005a:59) contends that the ecumenical movement's notion, "the earth is the Lord's", must be challenged, as it removes God from creation, places Him outside and portrays Him as the "owner" of creation, while denying the earth's integrity. She calls for "a holistic vision of interdependence" - an entirely new creative manner of perceiving life and resolving dualisms, schisms, and conflicts

${ }^{14}$ Narendra Singh (1987:1989). 
of the past. It "emphasizes the life that is in everything, the value of all God's bounty ... [and] affirms the sacredness of all God's gifts in creation" (Gnanadason, 1994:184). The earth should be considered sacred, and human evolution should be in harmony with nature's intellectual, emotional, and spiritual patterns (Gnanadason, 1996:79).

\section{Alternatives}

Gnanadason (2005a:2-3) notes that the "prudent practices" of India's Indigenous people who regard their very existence interwoven with the land - being particularly relevant for bridging the schisms effected by traditional dualisms and liberating all of creation from oppression. She calls it a spirituality, one that stresses the interconnectedness between humans and nature, also known as Purusha-Prakriti - "a duality in unity" not limited to a particular religion, culture, or tradition, but an indispensable element of all liberation movements and struggles across the globe (Gnanadason, 1992:36-38).

Considering the magnitude of the water crisis with regard to ecological degradation in India, Gnanadason (2005a:25) pays special attention to this issue. She notes that the ecumenical team who attended the $13^{\text {th }}$ Session of the United Nations Commission on Sustainable Development affirmed that as God-given gift, water should be conserved for the entire creation, not only humans. Being an integral part of creation our survival depends on the survival of the whole of the bio-system in which we exist - all of creation is inseparably intertwined. We should move from an "implicitly dualistic, hierarchical, individualistic and utilitarian subject-object relationship with God and the earth" to a "subject-subject relationship which affirms the intrinsic value and the integrity and goodness of all creation" (Gnanadason, 2005b:168). Gnanadason (2005b:169) believes that we should reclaim the earth as God's body, acknowledging its sacredness: "Our commitment to the earth and to peoples of the earth needs be held together in one frame" (Gnanadason, 2005a:37).

In the Orthodox tradition, humans are regarded the "microcosm" of creation. This idea reiterates the inseparable bond between God, humans, and the rest of creation (Gnanadason, 2005a:61). With this in mind, Gnanadason (2005a:64) quotes the following WCC statement (1988): "Creation came into being by the will and love of the triune God ... [E]very creature and the whole creation in chorus bear witness to the glorious unity and harmony with which the creation is endowed". Gnanadason (2005a:75-76) emphasises that God's salvation is intended for the entire creation, not just humankind. We are situated in the wider earth community encompassing all living and non-living creatures, "linked to each other in a web of relationships". We are "one whole".

\section{Conclusion}

Exploring the contemporary ecological crisis in the light of the nature of sin grants a fresh perspective on environmental concerns and offers new insights on where we have strayed and how our course can be adjusted. The point of departure would have to be a complete transformation of our beliefs, habits, as well as behavioural patterns. Aruna Gnanadason paves the way forward through her contribution to the ecological debate. Gaining a wellrounded perspective, however, necessitates some reflection and evaluation.

A prominent characteristic of Gnanadason's theology is her combination of Indigenous practice with Christian theology. Baumgardt (2012:176) commends her for highlighting central Christian truths, whilst drawing from Indigenous traditions, ethics, and voices, as well as ecofeminism, to confront biblical interpretations which could be harmful to the earth. Furthermore, Gnanadason emphasises Indigenous traditions and experiences by explaining it in Christian terms with the purpose of stressing the global responsibility to care for creation.

Gnanadason's interest in the poor, deprived, and oppressed adds a unique sense of 
compassion and concern to her ecotheology, which offers pioneering groundwork for further research and discussion in contemporary feminist and wider ecotheological circles. Her theology centres on the impoverishment and distress of the Dalit and Indigenous people of India who, in her words, have only in recent years come to know and are able to speak of their dignity as human beings, and are only now "becoming a people". Taking this into consideration, anthropocentrism is underplayed in her discussion of ecological sin. While all humans contribute to ecological devastation, one may not generalise as to the degree in which this occurs from one group of people or one individual to the next. Noting the influence of social and contextual factors is important: Scholars with lesser experience of social injustice appear to more easily critically distinguish and accept the burden of guilt for anthropocentrism compared to those for whom the opposite holds true, as in the case of Aruna Gnanadason.

Taking Gnanadason's home context with its various systems of domination and dualisms into account, justifies her accentuating domination in the name of differences of species as ecological sin. She advocates the rights of the oppressed and sufferers of injustice, especially women and the earth. The double-domination of the latter is a key element of her theology. Baumgardt (2012:175) perceives Gnanadason as a key "Third World" ecofeminist, using her background as a valuable source. She states: "I framed her theology as a response to a common target in her writings: the theology of dominion and its harmful, practical implications for women and the earth, especially but not exclusively in the third world".

Baumgardt (2012:181) argues that Gnanadason's work reveals a covert disregard or dismissal of knowledge incompatible with First World Western ideals. Her theology invites both Third and First World Christian theologians to acknowledge the effects of ecological degradation, and also creates opportunity for the latter to learn from Indigenous wisdom so often disregarded. Baumgardt (2012:163) recognises that Gnanadason's "theological approach to the third world also includes intentional interdisciplinary and interreligious sources that reflect the pluralism within her cultural context of India". She primarily uses this background for illustration of problems or possible solutions to the ecological crisis. According to Baumgardt (2012:164), the Christian tradition could gain immensely from Indigenous knowledge, wisdom, experiences, and practices in terms of creation care. She recognises how Gnanadason relates Indigenous prudent care to the concept of "brown grace", yet states that the notion of "prudence" in Christian theology could become problematic seeing that Gnanadason does not clearly define it (Baumgardt 2012:168). This is indeed true as the ecological crisis is a global phenomenon. Therefore, in order for "prudent care" to be applied in a global context, more practical examples and clearer illustrations are needed apart from just emphasising the Indigenous people's deep bonding with nature. Writing from a Christian perspective, Gnanadason, however, offers a foundation for inter-faith dialogue through the inclusion of Indigenous knowledge and practices.

Gnanadason primarily ascribes the alienation of humans from the earth community to various dualisms implicit in Western theology. She accentuates the sacred bond between women and the earth - a key aspect of her theology. Desjardins (2013:225) observes that many feminists are reluctant to support distinct and unique "woman ways" of experiencing and understanding the world. The notion of women being "closer to nature" than men contains an implicit dualism and only strengthens and supports hierarchical and dominating ways of thinking. He quotes Plumwood (1992:12) who perceives it as "perpetuating women's oppression in a new and subtle form", and King (1981:15) who refers to it as "unwitting complicity" in the patriarchal way of thinking underlying the human-nature dualism.

In suggesting alternatives to the aforementioned, Gnanadason suggests the adoption of a spirituality transcending all cultural and religious barriers. She also calls for deeper interconnectedness between humans and nature. Thus, instilling of a tradition of 'prudent care' is needed if environmental challenges are to be mitigated. Baumgardt (2012:171), however, criticises Gnanadason for not applying a consistent definition of "spirituality". Gnanadason 
(1992:37-40) outlines five facets of what she implies with the concept spirituality, the third one prominently standing out: "It is a celebration of the plurality of experiences. It rejects efforts to impose uniformity by a process of assimilation and integration, and encourages each group to assert its self-identity. It asserts the right to self-identity and autonomous existence." This clearly stands in opposition to Baumgardt's argument. Moreover, it proves that Gnanadason has no intention of consistently defining "spirituality" but intends for it to be understood and celebrated in its diversity and multifacetedness.

Gnanadason indeed makes a remarkable and unique contribution to the theological discourse an ecological debate and lays some essential groundwork for further research and discussion. Baumgardt $(2012: 172,181)$ states that Gnanadason's theology is "intrinsically ecumenical", revealing "how greater ecumenical, interreligious, intercultural, and interdisciplinary dialogues can become positive avenues for deepening our Christian sensibilities to environmental concerns".

Reversing the damage we inflicted might be impractical, but one thing indeed possible is moral and spiritual renewal. The key is educating ourselves on ecologically respectful ways of life. We humans share a profound connection with the entire creation, yet we have severed this relationship. What we need to do now is, through recognition of our Creator, re-connect with our fellow creatures in ways previously deemed impossible.

\section{References}

Aquinas, (St.). T. (1991). Summa Theologica: A Concise Translation, Christian Classics: Allen, Texas.

Barth, K. (1958). Church Dogmatics, Vol III/1: The Doctrine of Creation, T. \& T. Clark: Edinburgh.

Barth, K. (1960). Church Dogmatics, Vol III/3: The Doctrine of Creation, T. \& T. Clark. Edinburgh.

Barth, K. (1961). Church Dogmatics, Vol IV/1: The Doctrine of Reconciliation, T. \& T. Clark: Edinburgh.

Baumgardt, G. (2012). Opening First-World Catholic Theology to Third-World Ecofeminism: Aruna Gnanadason and Johann B. Metz in Dialogue, Thesis: Marquette University.

Brinkman, M.E. (2003). The Tragedy of Human Freedom. The Failure and Promise of the Christian Concept of Freedom in Western Culture, Rodopi: Amsterdam.

Brunner, E. (1952). The Christian Doctrine of Creation and Redemption, Dogmatics, Vol 2, Westminster: Philadelphia.

Cloete, N. (2013). Hamartology and Ecology: A Critical Assessment of Dietrich Bonhoeffer's View on the Nature of Sin, Thesis: UWC.

Conradie, E.M. (2006). Christianity and Ecological Theology, Sun Press: Stellenbosch.

Conradie, E.M. (2017). Redeeming Sin? Lexington Books: London.

Desjardins, J.R. (2013). Environmental Ethics: An Introduction to Environmental Philosophy, $5^{\text {th }}$ Edition, United States: Wadsworth.

Dietrich, G. (1996). The World as Body of God: Feminist Perspectives on Ecology and Social 
Justice. In R.R. Ruether (Ed.), Women Healing Earth, Orbis, Maryknoll.

Durand, J.J.F. (1978). Die Sonde, N.G. Kerkboekhandel: Pretoria.

Engel, M.P. (1990). Evil, Sin and Violation of the Vulnerable. In S.B. Thistlethwaite \& M.P. Engel (Eds.), Lift Every Voice, Harper \& Row: San Francisco.

Fowler, R.B. (1995). The Greening of Protestant Thought, University of North Carolina: Chapel Hill NC.

Gebara, I. (1999). Longing for Running Water: Ecofeminism and Liberation, Fortress: Minneapolis.

Gnanadason, A. (1992). A Spirituality that Sustains Us in Our Struggles, International Review of Mission, 80(317), 29-41.

Gnanadason, A. (1994). Women, Economy and Ecology. In D. Hallman (Ed.), Ecotheology: Voices from South and North, Maryknoll, Orbis: New York, 179-185.

Gnanadason, A. (1996). Toward a Feminist Eco-Theology for India. In R.R. Ruether (Ed.), Women Healing Earth, Orbis: Maryknoll, 74-81.

Gnanadason, A. (2004). The Integrity of Creation and Earth Community: An Ecumenical Response to Environmental Racism, Union Seminary Quarterly Review, 58, 97-119.

Gnanadason, A. (2005a). Listen to the Women! Listen to the Earth! Geneva: WCC.

Gnanadason, A. (2005b). Yes, Creator God, Transform the Earth! The Earth as God's Body in an Age of Environmental Violence, The Ecumenical Review, 57(2), 159-170.

Gnanadason, A. (2006). We Have Spoken So Long O God: When Will We Be Heard? Theological Reflections on Overcoming Violence against Women, Theology \& Sexuality, 13(1), 9-22.

Grdzelidze, T (2002). How does the Orthodox church respond to Ecological Problems?, The Ecumenical Review, 54(3), 211-218.

Horrell, D.G. 2010. The Bible and the Environment: Toward a Critical Ecological Biblical Theology, Equinox: London.

King, Y. (1981). Feminism and the Revolt against Nature, Heresies \#13: Feminism and Ecology, 4, 15.

McDaniel, J (1997). The Sacred Whole: An Ecumenical Protestant Approach. In J. Carroll, P. Brockelman and M. Westfall (Eds.), The Greening of Faith, Univ. Press of New England: London.

McFague, S. (1997). Super, Natural Christians: How We should Love Nature, Fortress Press: Minneapolis.

Moltmann, J. (1985). God in Creation, SCM: London.

Nalunnakkal, G.M. (1999). Green Liberation: Towards an Integral Ecotheology, ISPCK/NCCI: Delhi.

Nash, J.A. (1996). Towards the Ecological Reformation of Christianity, Interpretation, Vol 
50(1), 5- 15.

Niebuhr, R. (1941/1996). The Nature and Destiny of Man, Vol. 1, John Knox: Westminster.

Peralta, A. (2004). Women and Economic Globalisation: A Discussion Paper, Justice and Creation Team, Geneva, WCC.

Peters, T. (1994). Sin, Eerdmans: Grand Rapids.

Plumwood, V. (1992). ‘Feminism and Ecofeminism', Ecologist, Vol. 22, 12.

Robinson, H.W. (1911). The Christian Doctrine of Man, T. \& T. Clark: Edinburgh.

Ruether, R.R. (1992). Gaia and God: An Ecofeminist Theology of Earth Healing, HarperCollins: New York.

Russell, L.M. (1985). Feminist Interpretation of the Bible, Westminster: Philadelphia.

Santmire, H.P. (1985). The Travail of Nature, Fortress Press: Philadelphia.

Shiva, V. (1989). Staying Alive: Women, Ecology and Development, Zed Books: London.

Singh, N. (1987). Robert Solow's Growth Hickonomics. In Economic and Political Weekly, XXII (45), 1983.

Tillich, P. (1957). Systematic Theology, Vol. 2, University of Chicago Press. Chicago:.

WCC (1988). Granvollen Final Document, Integrity of Creation-An Ecumenical Discussion, JPIC Resource Materials, 3(2), 3-16.

White Jr., L. (1967). The Historical Roots of Our Ecological Crisis, Science, 155, 1203-7.

Williams, R.R. (1985). Sin and Evil. In P.C. Hodgson \& R.H. King (Eds.), Christian Theology. An Introduction to its Traditions and Tasks, Fortress: Philadelphia, 194-219. 